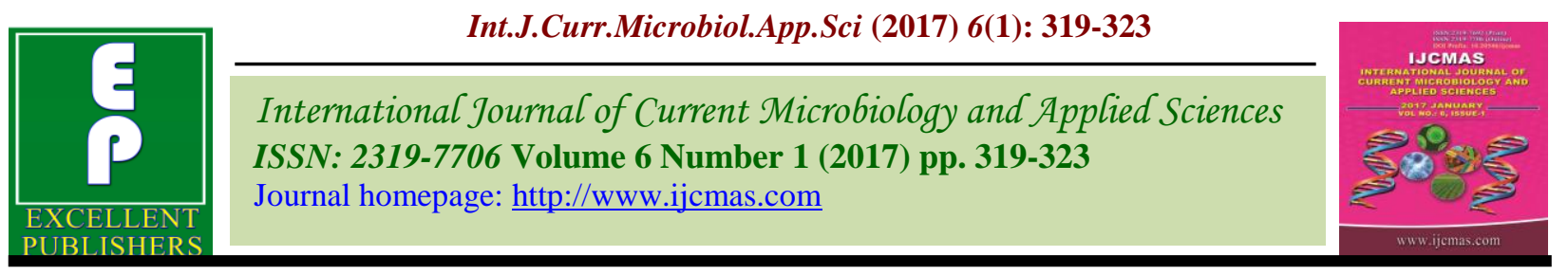

Original Research Article

http://dx.doi.org/10.20546/ijcmas.2017.601.039

\title{
Utility of Pap Smear in Cervical Screening in a Tertiary Care Hospital
}

\author{
K. Vijaya ${ }^{1}$ and R. Shyamala ${ }^{2 *}$ \\ ${ }^{1}$ Department of Pathology, Mallareddy Medical College for Women, \\ Hyderabad, Telangana, India \\ ${ }^{2}$ Department of Microbiology, Mallareddy Medical College for Women, \\ Hyderabad, Telangana, India \\ *Corresponding author
}

\section{A B S T R A C T}

Keywords

Cervical Cancer, Papsmear, Bethesda System.

\section{Article Info}

Accepted:

18 December 2016

Available Online:

10 January 2017
This study was conducted to analyse the incidence of various lesions of uterine cervix, inflammatory as well as malignant and to find the age group of patients who can benefit from this screening. Smears were collected from 325 patients in the age group 20 to 70 years, between July 2014 to December 2016. These patients complained of white discharge, pain abdomen, post menopausal bleeding and mass per vagina. The slides were fixed in $95 \%$ ethyl alcohol, and stained with PAP stain. The slides were screened according to 2001 Bethesda System by two cytopathologists. Out of 325 smears studied 220 showed inflammatory pathology, 54 were premalignant and 7 were diagnosed as malignant.

\section{Introduction}

Cancer of uterine cervix is the most common cause of mortality and morbidity among women both in developed and developing countries next to cancer breast (Parkin et al., 2001). But in Indian women it is the commonest malignancy followed by to cancer breast (Gustafsson, 1997).

It constitutes about $8 \%$ of all cancers in developing countries. Every year about 5 lakhs new cases are diagnosed globally, leading to death in more than $50 \%$ of these case. One fourth of these cases occur in India. Early detection of these cases using pap smear screening is required to reduce the mortality rate (Mulligan, 1998).
Pap smear is a simple, safe, reliable and non invasive method for detecting cancerous, precancerous and non neoplastic changes in the cervix. The Bethesda system is the most widely used system for describing pap smear result (TBS-2001) (Thomas, 2002).

\section{Materials and Methods}

This retrospective study was done at Malla reddy Medical college for women, Hyderabad. Pap smears from 325 patients who presented to the pathology department between July 2014 to December 2016 were analysed. The age of these patients ranged from 20 to 70 years. These patients presented 
with complaints of white discharge, excessive bleeding per vagina, post menopausal bleeding and mass per vagina. The smears were taken by a gynaecologist using Ayres wooden spatula under aseptic precautions. The material was smeared on a labeled glass slide, fixed in $95 \%$ ethyl alcohol and stained by pap stain.After staining they were mounted with DPX,screened and reported by two cytopathologists according to the Bethesda system, 2001.

This study was done to know the prevalence of various premalignant, malignant and non neoplastic lesions of cervix using pap smear.

\section{Results and Discussion}

A total of 325 cervical smears during the period July 2014 to December 2016were studied,out of which 220 smears(67\%) showed inflammatory changes, 20(6\%) smears were inadequate and $20(6 \%)$ were normal..4 showed (1\%) atrophic changes,
25(7\%) -ASCUS (Atypical Cells of Undetermined Significance) 5(1\%) -AGUS (Atypical Glandular cell of Undetermined Significance), 19 (5\%) -LSIL (Low grade Squamous Intraepithelial Lesion, 5 (1\%) HISL (High grade Squamous Intraepithelial Lesion) (1\%) and 7(2\%) squamous cell carcinoma.

The ratio of neoplatic to non neoplastic was 61:220:, and the ratio of premalignant to malignant was 54:7. ASCUS and AGUS constituted about $49 \%$ of the neoplastic lesions. ASCUS progresses to LSIL, HSIL and SCC. AGUS progresses to adenocarcinoma.

Cervical cancer is the leading cause of death among Indian women. It is the 4th common cancer causing death in them and its increasing incidence can be attributed to changing lifestyles. It is more common in the rural than urban areas, due to non availability of screening methods, illiteracy and poverty.

Table.1 Age wise distribution of various neoplastic and nonneoplastic lesions of cervix

\begin{tabular}{|l|l|l|l|l|l|l|l|l|}
\hline Age & Inflammatory & Normal & Atrophic & Ascus & Agus & LSIL & HSIL & CARCINOMA \\
\hline $20-29$ & 71 & 7 & & 01 & & & & \\
\hline $30-39$ & 59 & 3 & & 20 & 04 & 09 & 03 & \\
\hline $40-49$ & 48 & 5 & 2 & 04 & 01 & 06 & & \\
\hline $50-59$ & 30 & 5 & 2 & & & 04 & 02 & 05 \\
\hline $60-70$ & 12 & & & & & & & 02 \\
\hline TOTAL & 220 & 20 & 4 & 25 & 5 & 19 & 5 & 7 \\
\hline
\end{tabular}

Table.2 Comparison of findings of pap smear cytology with our study

\begin{tabular}{|l|l|l|l|l|l|l|}
\hline & $\begin{array}{l}\text { Present } \\
\text { study }\end{array}$ & $\begin{array}{l}\text { Thomas } \text { et } \\
\text { al } 2002\end{array}$ & $\begin{array}{l}\text { Karuna } \text { et } \\
\text { al } 2003\end{array}$ & $\begin{array}{l}\text { M.S Bal } \text { et } \\
\text { al2012 }\end{array}$ & $\begin{array}{l}\text { Beinton } \text { et } \\
\text { al1986 }\end{array}$ & $\begin{array}{l}\text { Bajpai } \text { et } \\
\text { al2016 }\end{array}$ \\
\hline ASCUS & $6 \%$ & $15.3 \%$ & $6 \%$ & $0.3 \%$ & $6.9 \%$ & $0.3 \%$ \\
\hline LSL & $5 \%$ & $14.1 \%$ & $7 \%$ & $2.7 \%$ & $8.4 \%$ & $1.3 \%$ \\
\hline HSIL & $1 \%$ & $5.8 \%$ & $5 \%$ & $0.7 \%$ & $2.6 \%$ & $0.6 \%$ \\
\hline CA & $2 \%$ & & & $1.3 \%$ & $2.6 \%$ & $0.3 \%$ \\
\hline
\end{tabular}


Fig.1 Photomicrograph of ASCUS showing atypical squamous cells (papx400)

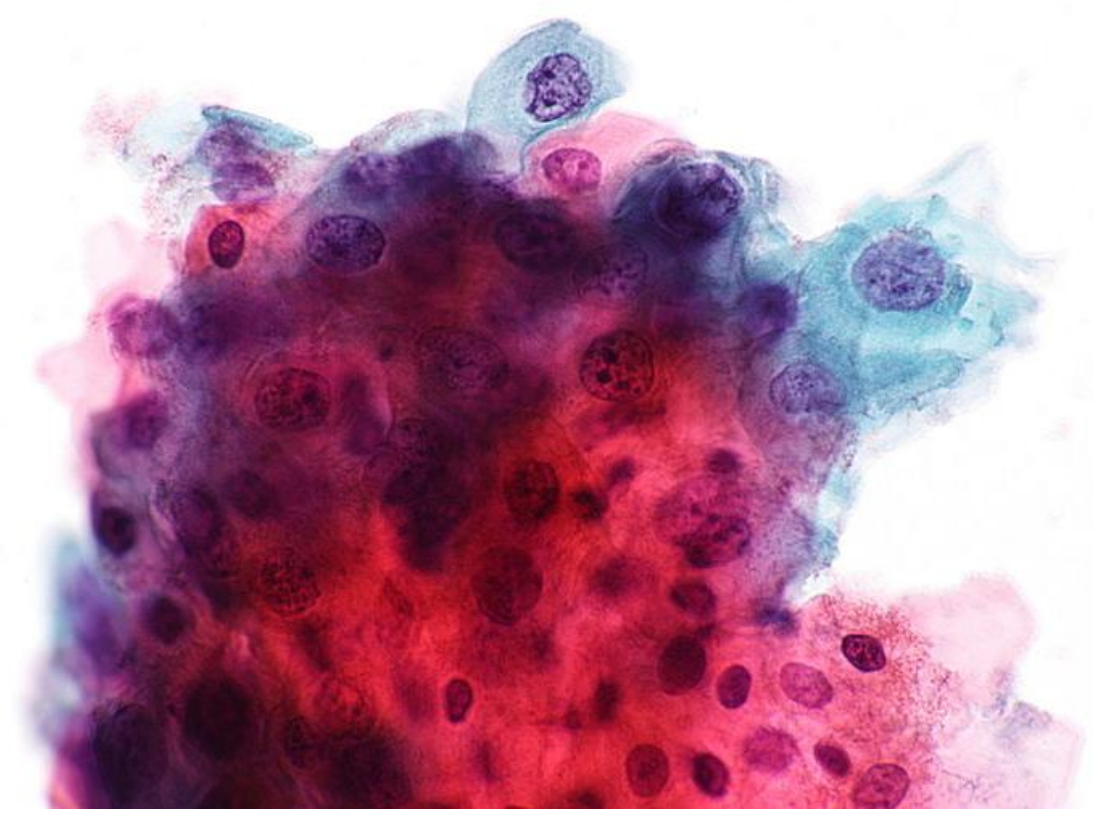

Fig.2 Photomicrograph of LSILshowing a groupof parabasal cells with anisonucleosis(papx400)
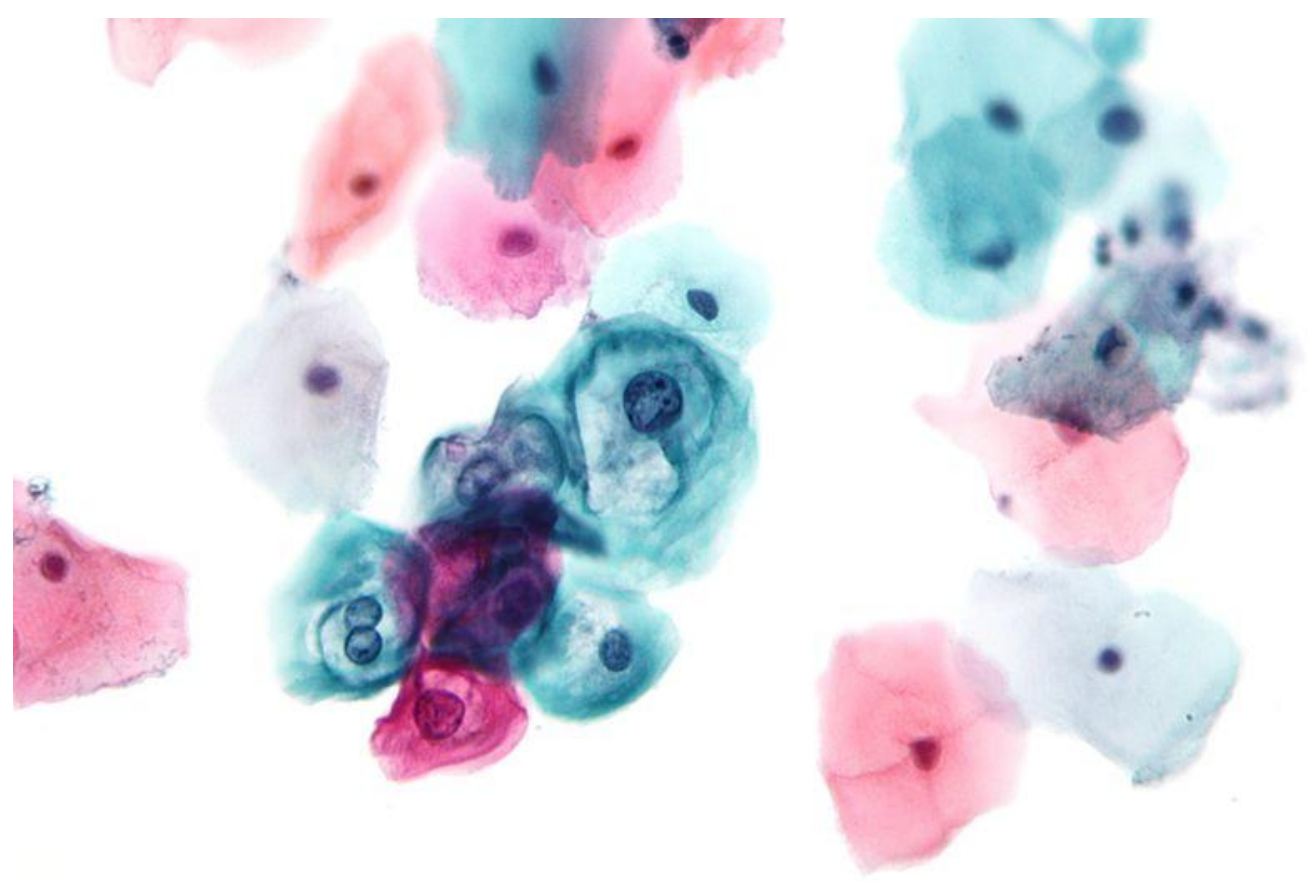
Fig.3 Photomicrograph of squamous cell carcinoma showing malignant cells with nucleomegaly and hyperchromatic nuclei, irregular nuclear margins and strap cells. (papx400)

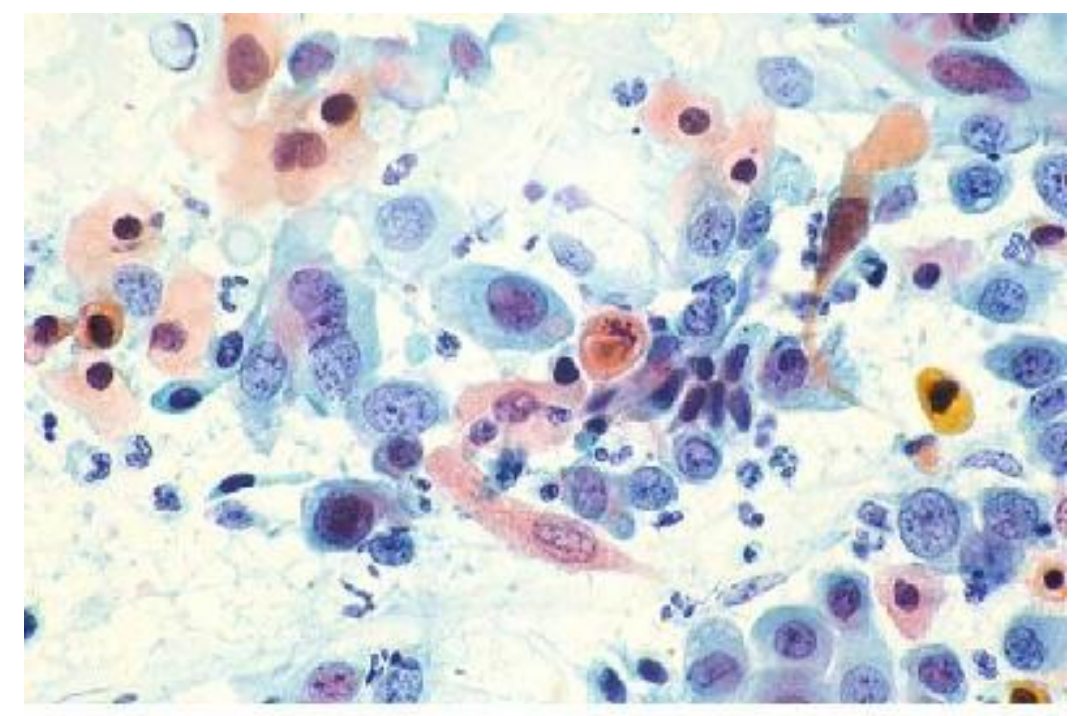

Appropriate mass screening programmes are required to detect precancerous lesions and thereby prevent their progress to cancer. In our study $67 \%$ were inflammatory lesions, $19 \%$ were premalignant. Out of the premalignant lesions ASCUS and AGUS were $55 \%$. ASCUS was observed in the age group30to50years.

The findings in our study correlated with other studies. Pap smear screening can be advocated to all women above 30 years and above. It is a gold standard for cervical screening programmes, although a variety of screening tests like liquid pap cytology, automated cervical screening techniques, visual inspection of cervix after lugol's iodine and acetic acid application are available (Kerkar, 2006).

WHO has recommended screening every woman once in her life time after 40 years (Beinton, 1986).The American cancer society recommends screening all women starting from 3 years after first coitus and repeat after
1-2 years. The sensitivity can be increased by combining with HPV-DNA testing

In conclusion, pap smear examination is a effective screening method accepted worldwide. If inconclusive biopsy is indicated in suspicious cases. It can help immensely in detecting premalignant lesions and further prevent their progress to malignancy.Long term screening programmes especially in rural India can help in early detection of these cases.

\section{References}

Beinton, A., Palintasa, Barrett, Conner. 1986. estrogen depressive symptoms in post menopausal women, J. Obs. Gynecol., 80(1): 30-33.

Cioc, A.M., Julius, C.J., Proca, D.M., Tranovich, V.L., Keyhani-Rofaga, S. 2002. Cervical biopsy/ cytology correlation data can be collected prospectively and shared clinically. Diagn. Cytopathol., 26(1): 49-52, 
PMID:11782088.

Gustafsson, L., Ponten, J., Zack, M., Adami, H.O. 1997. International incidence rates of cervical cancer after introduction cytological screening. Cancer Causes Control, 8(5): 755-63, PMID: 9328198

Kerkar, R.A., Kulkarni, Y.V. 2006. Screening for cervicalcancer: An overview. $J$. Obstet. Gynecol. India, 56: 115-22.

Mulligan, N.J., Delas Morenas, A. 1998. Soto -Wright V, Obrien MJ. Percentages of cervical cytologic dignoses as a quality assurance method. Acta Cytol., (4): 928-
34PMID: 9684579.

Parkin, D.M., Bray, F.I., Devesa, S.S. 2001. Cancer burden in the year 2000, The Global picture. Eur. J. Cancer, 37 Suppl 8: 54-66, PMID :11602373

Thomas, A., Corrara, Majoria, M.A., Kumar, K.R. 2002. The Bethesda system recommendation in reporting lining endometrial cells in cervical smears from postmenopausal women Published by American Cancer Society. Indian J. Pathol. Microbiol., 25(1): 134.

\section{How to cite this article:}

Vijaya, K., and Shyamala, R. 2017. Utility of Pap Smear in Cervical Screening in a Tertiary Care Hospital. Int.J.Curr.Microbiol.App.Sci. 6(1): 319-323.

doi: http://dx.doi.org/10.20546/ijcmas.2017.601.039 